\title{
A novel non-mineral oil-based adjuvant. II. Efficacy of a synthetic sulfolipopolysaccharide in a squalane-in-water emulsion in pigs
}

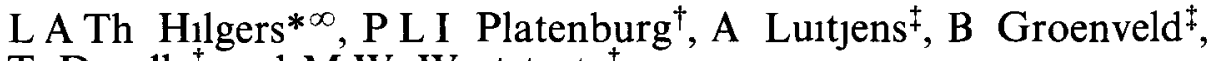 \\ T Dazelle and $^{\ddagger}$ W Weststrate
}

The adjuvanticity of a sulfolipopolysaccharide (SLP) incorporated into a squalane-inwater emulsion $(S L P / S / W)$ was compared with that of a mineral oll-in-water $(O / W)$ adjuvant currently used in commercial porcine vaccines Groups of pigs were immunized twice with vaccines comprising either inactwated influenza virus (IFlu3 containing strains A/Swine, MRC-11 and X-79), inactivated pseudorabies virus (IPRV), live pseudorabies virus $(P R V)$ or inactivated porcine parvovirus ( as adjuvant Antibody titres in serum 2 or 3 weeks after the second immunization were measured by haemagglutination inhibition (HI) or serum neutralization (SN) assays Both adjuvants significantly augmented the antibody responses against the antigens tested Mean factors of increase obtained by $S L P / S / W$ and $O / W$ were 315 and 91 , respectively, for A/Swine, 478 and 137 for $M R C-11,362$ and 128 for $X-79,69$ and 49 for $\imath P R V$, and 23 and 7 for live $P R V$ Increased humoral immunity against live PRV was affirmed by reduced levels and duration of virus excreted by pigs after challenge with virulent $P R V$ Immunization of pigs with $1 P P V$ plus adjuvant $S L P / S / W$ gave 36-fold higher titres than with $O / W$ It was concluded that $S L P / S / W$ is more effective than $O / W$ in stimulating humoral immunity against the viral antigens examined and that the two constituents $S L P$ and $S / W$ interact synergistically Advantages of $S L P / S / W$ over $O / W$ include stronger adjuvanticity, better biocompatibllity and lower doses of active substances

Keywords Adjuvant, sulfolipopolysaccharıde, efficacy, pıgs, synthetıc polymer, squalane-1n-water emulsıon, ımmunostımulation, viral vaccines

The most common types of adjuvants used in vaccines for domestic food animals are still emulsions of either the oll-in-water or water-in-oil type, based on oil of mineral origin In general, these adjuvants exhibit strong activity with a wide range of antigens but, possibly owing to limited biodegradability and biocompatibility, their application is often accompanied with certain side-effects and risks Parenteral administration of mineral oil emulsions into anımals frequently provokes reactions at the site of injection of which the severity and duration depend on the nature and concentration of the onl and physicochemical characteristics of the emulsions ${ }^{1}$ Studies on the kinetics of mineral oil emulsions in vivo demonstrated that considerable quantities of oil remained

\footnotetext{
*Solvay SA, Research and Technology, Central Laboratory, Applied Immunology, Rue de Ransbeek 310, 1120 Brussels, Belgium 'Erasmus Unıversity of Rotterdam, Department of Immunology, Rotterdam, The Netherlands ₹ Solvay Duphar BV, Anımal Health Divisıon, Bıological Development Group, Weesp, The Netherlands ${ }^{\infty}$ To whom correspondence should be addressed (Received 10 March 1993, revised 5 October 1993, accepted 11 October 1993)
}

at the site of injection ${ }^{2,3}$ and in other anatomic compartments $^{4}$ for a long period of time As a consequence of this persistence, it cannot be excluded that consumers of food of animal origin are exposed to oll residues and although detrimental effects of such residues are not exhaustively documented, they might introduce certain risks to human health In addition, there exist also risks to veterinary surgeons or anımal handlers of accidental autoinjection For these reasons, replacement of the mineral oil components while retaining adjuvanticity but reducing risks is very desirable Several attempts have been described and a few veterinary vaccines are at present on the market supplemented with novel adjuvants e g vitamin $\mathrm{E}$, polyacrylate resins (Carbopol, of B F Goodrich), acetylated polymannose (Acemannan, Carrıngton Labs) and avridıne Emulsıons of olls of vegetable origin such as peanut, olive, sesame oil etc $^{5-8}$ or of animal origin, e g squalane and squalene ${ }^{9}$, have also been investigated but activity was almost always insufficient compared to mineral oil

In an accompanying paper ${ }^{10}$ we have described the adjuvanticity of a synthetic, high-molecular-weight polysucrose derivatized with fatty acid esters and sulfate 
groups and incorporated in a squalane-in-water emulsion towards various proteinic and viral antigens in laboratory animals Effects of this adjuvant formulation on immune responses against a number of porcine viral antigens in the target anımal species are reported here

\section{MATERIALS AND METHODS}

\section{Animals}

Pigs of 8-10 weeks of age were screened for the presence of antibodies against the viral antigens in question and anımals with detectable antıbody titres were excluded

\section{Vaccines}

Antigens were prepared as described previously ${ }^{10}$ The following doses of antigen (corresponding to $1 \mathrm{ml}$ of antigen solution) were injected $44 \mu \mathrm{g}$ influenza virus $\mathrm{A} / \mathrm{Sw}$ ine $+40 \mu \mathrm{g}$ MRC-11+20 $\mu \mathrm{g}$ X-79 (1Flu3), $10^{8}$ TCID $_{50}$ inactivated pseudorabies virus (1PRV), $10^{5}$ TCID $_{50}$ live pseudorabies virus (PRV), and $10^{5}$ TCID $_{50}$ inactivated porcine parvovirus (1PPV) Adjuvants tested have been described elsewhere ${ }^{10}$ Vaccines were obtained by either mixing 1 volume of antigen with 1 volume adjuvant solution or resuspending lyophilized virus (live PRV) in distilled water or adjuvant solution diluted with an equal volume of distilled water

\section{Vaccination}

Groups of at least five pigs were injected twice intramuscularly $(1 \mathrm{~m})$ with $20 \mathrm{ml}$ vaccine per animal at weeks 0 and 3 and blood was collected 2 or 3 weeks after the second immunization

\section{Antibody titres against influenza and pseudorabies virus}

Ant1-influenza and antı-pseudorabies virus antıbody titres were measured as described previously ${ }^{10}$

\section{Antıbody titres against PPV}

Serum samples were inactivated by incubating for 30 min at $56^{\circ} \mathrm{C}$ and pretreated with 3 volumes of kaolin suspension (ICN/Flow Labs, Irvine, UK) and twice with 1 volume of a suspension of $50 \%$ guinea-pig red blood cells (GpRBC) in PBS Then, $50 \mu$ of the serum samples were diluted in PBS in 96-well plates and $50 \mu$ l of a virus suspension containing $8 \mathrm{HA}$ PPV were added to the serum dilutions After incubation for $45 \mathrm{~min}$ at room temperature, $50 \mu \mathrm{l}$ of a $06 \% \mathrm{GpRBC}$ suspension in PBS were added After 1-2 h, agglutination was detected and the reciprocal value of the highest serum dilution demonstrating $\mathrm{HI}$ was considered to be the titre

\section{Virus excretion upon challenge with virulent PRV}

Virus excreted after challenge with virulent PRV was determined by the method described by Vannier et al ${ }^{11}$ Briefly, nasal swabs were taken daily from individual pigs from before challenge to 12 days postchallenge The swabs were weighed before and after sampling and soaked in $2 \mathrm{ml}$ of culture medium and stored at $-70^{\circ} \mathrm{C}$ for a maximum of 14 days Samples of $100 \mu$ l of these culture media were taken and the numbers of plaqueforming units were determined The means $( \pm \mathrm{s}$ e $\mathrm{m})$ were calculated of the $10-\log$ of $\mathrm{TCID}_{50}$ on $\mathrm{PD}_{5}$ cells per gram of mucus

\section{Statıstical analysıs}

Analysis of samples was performed by standardized tests and criteria for validity have been described before $^{10}$ Student's $t$ test was carried out to analyse statistical significance of the results and $p>005$ was considered to be significant

\section{RESULTS}

\section{Effect of SLP/S/W on the antibody response against iFlu3 in pigs}

In five independent experiments, groups of pigs were immunized twice with a combination of three influenza virus strains plus different adjuvants, and blood samples were taken 3 weeks after the second vaccination Antibody titres achieved by either SLP/S/W, S/W or SLP were compared with those of antigen alone or antigen plus $\mathrm{O} / \mathrm{W}$ (Figure 1 )

In general, differences in titres against the three virus strains were seen between the individual experiments and responses against $\mathrm{A} / \mathrm{Sw}$ we were lower than those against the two other strains The mean factors of increase in responses to A/Swine, MRC-11 and X-79 observed varied
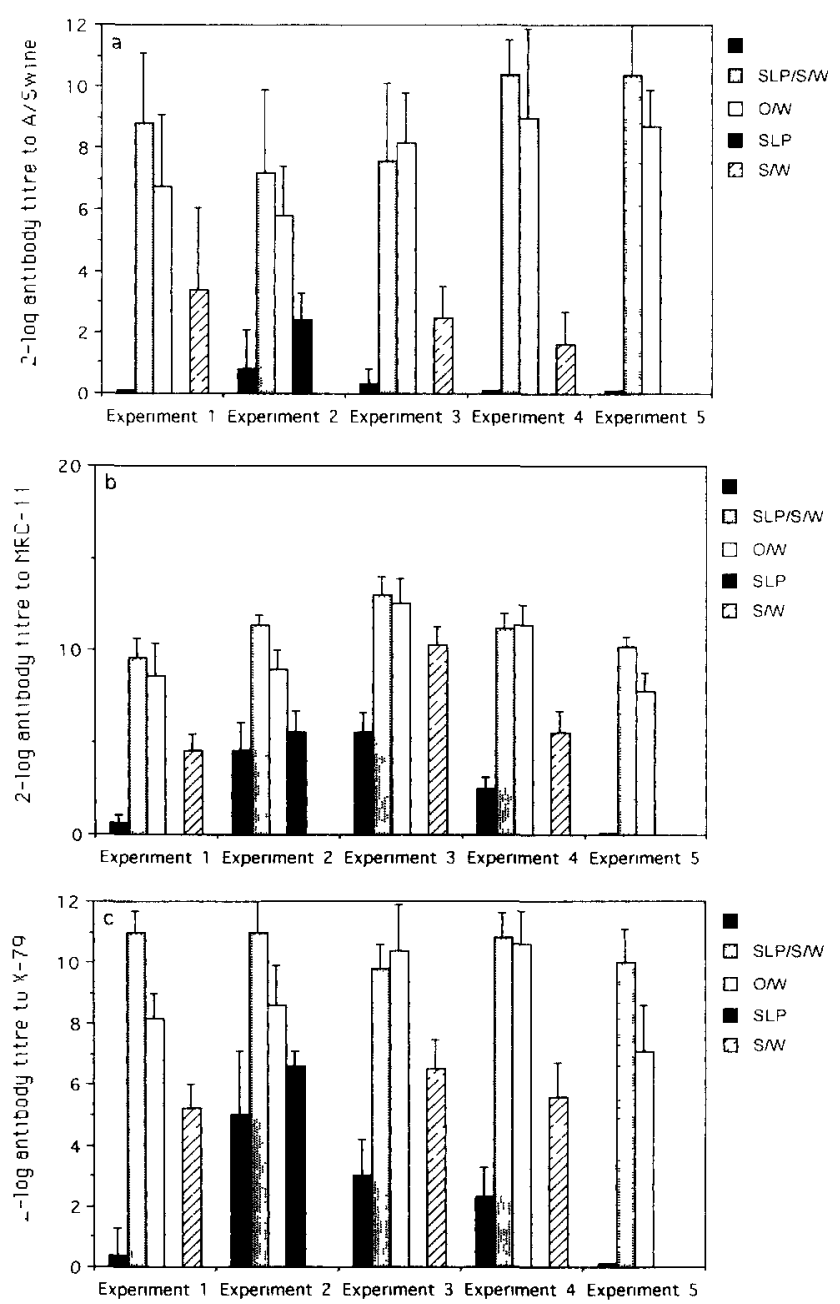

Figure 1 Effect of various adjuvants on the antibody response against influenza virus (a) A/Swine, (b) MRC-11 and (c) X-79 in pigs after two vaccınatıons Mean values for at least five anımals are represented and vertical bars indıcate $\mathrm{se} \mathrm{m}$ 
Table 1 Comparison of the effect of varıous adjuvants on the antıbody responses to IFlu3 in pıgs

\begin{tabular}{|c|c|c|c|c|c|c|c|c|c|c|c|c|c|c|}
\hline \multirow[b]{3}{*}{ Group } & \multirow[b]{3}{*}{ Adjuvant } & \multirow[b]{3}{*}{$n$} & \multicolumn{12}{|c|}{ 2-log antıbody tıtres at week 6 agaınst } \\
\hline & & & \multicolumn{4}{|c|}{ A/Swıne } & \multicolumn{4}{|c|}{ MRC-11 } & \multicolumn{4}{|c|}{$x-79$} \\
\hline & & & Mean & se m & FOI & $\mathbf{S}$ & Mean & se m & FOI & S & Mean & se m & FOI & $S$ \\
\hline 1 & - & 25 & 08 & 06 & - & $a$ & 27 & 08 & - & $a$ & 21 & 11 & - & $a$ \\
\hline 2 & $\mathrm{O} / \mathrm{W}$ & 30 & 73 & 18 & 91 & $b$ & 98 & 12 & 137 & $b$ & 91 & 09 & 128 & $b$ \\
\hline 3 & SLP/S/W & 35 & 91 & 16 & 315 & $c$ & 116 & 11 & 478 & $c$ & 106 & 08 & 362 & $c$ \\
\hline 4 & $S / W$ & 15 & 25 & 21 & 3 & $d$ & 68 & 09 & 17 & $d$ & 58 & 09 & 13 & $d$ \\
\hline 5 & SLP & 5 & 24 & 09 & 3 & $d$ & 56 & 11 & 7 & $e$ & 66 & 05 & 23 & $d$ \\
\hline
\end{tabular}

Results of the five independent experıments of Figure 1 were taken together Pigs were immunized intramuscularly with IFlu3 plus different adjuvants at weeks 0 and 3 and antibody titres were measured at week 6 by $\mathrm{HI}$ Mean value, se $\mathrm{m}$, factor of increase (FOl) and statıstical significance (S) of the results are represented Groups which are not statıstically different $(\rho>005)$ are indicated by the same letter

Table 2 Comparison of the effect of various adjuvants on the antibody responses against IPRV and IIve PRV in pigs

\begin{tabular}{|c|c|c|c|c|c|c|c|c|c|c|c|}
\hline \multirow[b]{3}{*}{ Group } & \multirow[b]{3}{*}{ Adjuvant } & \multicolumn{10}{|c|}{$2-\log$ antıbody titres at week 6 agaınst } \\
\hline & & \multicolumn{5}{|c|}{ IPRV } & \multicolumn{5}{|c|}{ Live PRV } \\
\hline & & $n$ & Mean & se m & FOI & $\mathrm{S}$ & $n$ & Mean & s e m & FOI & $\mathrm{S}$ \\
\hline 1 & - & 25 & 13 & 07 & - & $a$ & 20 & 75 & 11 & - & $a$ \\
\hline 2 & O/W & 30 & 69 & 15 & 49 & $c$ & 20 & 103 & 14 & 7 & $b$ \\
\hline 3 & SLP/S/W & 35 & 74 & 20 & 69 & $c$ & 20 & 120 & 14 & 23 & $c$ \\
\hline 4 & S/W & 15 & 32 & 13 & 4 & $b$ & & NT & & & \\
\hline 5 & SLP & 5 & 40 & 17 & 4 & $b$ & 5 & 90 & 16 & 3 & $b$ \\
\hline
\end{tabular}

NT, not tested

Results of the five independent experıments of Figures 2 and 3 were taken together Pigs were immunized intramusculariy with IPRV or live PRV plus different adjuvants at weeks 0 and 3 and antıbody titres were measured at week 6 by SN Mean value, s e $m$, factor of increase (FOI) and statıstıcal sıgnificance (S) of the results are represented Groups which are not statıstically different $(p>005)$ are indicated by the same letter

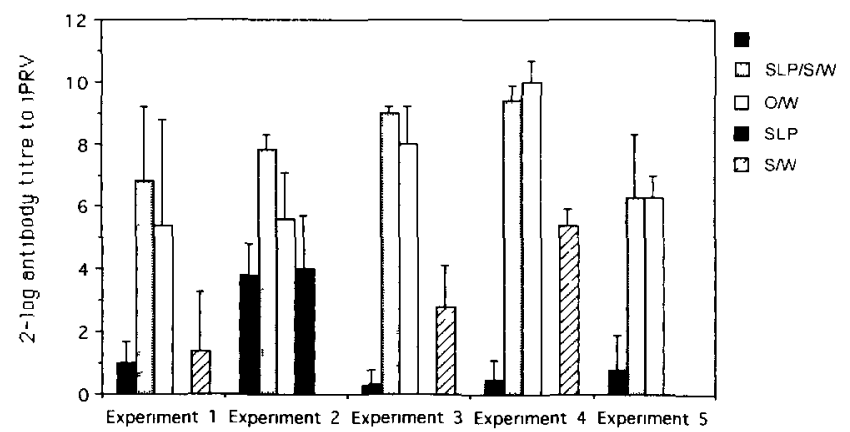

Figure 2 Effect of various adjuvants on the antibody response against IPRV in pigs after two vaccinations Mean values for at least five anımals are represented and vertical bars indicate $\mathrm{s}$ e $\mathrm{m}$

from 3 to 23 for SLP, 3 to 17 for $S / W, 91$ to 137 for $\mathrm{O} / \mathrm{W}$, and 315 to 478 for SLP/S/W (Table 1) SLP/S/W proved to be significantly more effective than either SLP, $\mathrm{S} / \mathrm{W}$ or $\mathrm{O} / \mathrm{W}$

\section{Stimulation of antibody responses to iPRV by SLP/S/W in pigs}

In five separate experiments the effect of SLP/S/W on the antıbody titre against inactivated PRV was compared with that of $\mathrm{O} / \mathrm{W}, \mathrm{SLP}$ or $\mathrm{S} / \mathrm{W}$, or with antigen alone (Figure 2) Both SLP and S/W induced mean fourfold increases whereas $\mathrm{O} / \mathrm{W}$ and SLP/S/W evoked increases of 49- and 69-fold, respectively (Table 2) S/W and SLP were significantly less effective than SLP/S/W in stımulatıng antıbody responses against $1 P R V$

\section{Effect of SLP/S/W on the antibody responses against live PRV in pigs}

The effect of SLP/S/W, SLP and O/W on the antibody response against live PRV was studied in four separate

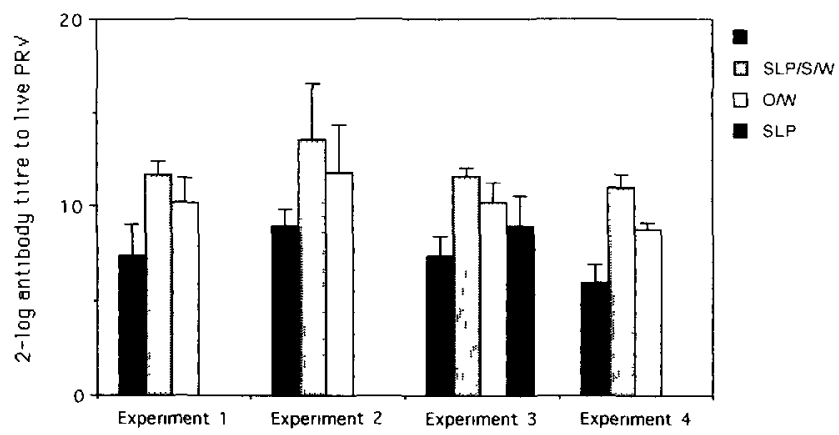

Figure 3 Effect of various adjuvants on the antibody response against live PRV in pigs after two vaccinations Mean values for five anımals are represented and vertıcal bars indıcate $s$ e $m$

experiments in pigs Anımals were immunized twice with an interval of 3 weeks and antibody titres were measured 3 weeks after the second vaccination (Figure 3) SLP/S/W and $\mathrm{O} / \mathrm{W}$ significantly augmented the humoral response against live PRV with a factor of 23 and 7, respectively (Table 2) SLP/S/W was significantly more effective than $\mathrm{O} / \mathrm{W}$ SLP alone induced a slight, significant enhancement of antibody titres

\section{Effect of SLP/S/W and $O / W$ on virus excretion upon challenge}

Groups of five pigs were vaccinated twice with a time interval of 3 weeks, 5 weeks after the second vaccination, they were challenged with virulent PRV Two out of five non-vaccinated control animals died shortly after challenge All animals that received live PRV vaccine with or without adjuvant survived the challenge

Virus titres in tonsillar swabs were monitored over 14 consecutive days (Figure 4) Geometric means of the number of virus particles $\left(\mathrm{TCID}_{50}\right)$ per gram sample were 
Table 3 Effect of O/W and SLP/S/W on the antibody response against IPPV in pigs

2-log antibody titres agaınst PPV at

\begin{tabular}{|c|c|c|c|c|c|c|c|c|c|c|c|}
\hline \multirow[b]{2}{*}{ Group } & \multirow[b]{2}{*}{ Adjuvant } & \multirow[b]{2}{*}{$n$} & \multicolumn{3}{|c|}{ Week 0} & \multicolumn{3}{|c|}{ Week 3} & \multicolumn{3}{|c|}{ Week 6} \\
\hline & & & Mean & se m & $s$ & Mean & sem & $s$ & mean & sem & $\mathrm{s}$ \\
\hline 1 & O/W & 5 & $<30$ & 00 & $a$ & 50 & 09 & $a$ & 56 & 19 & $a$ \\
\hline 2 & $S L P / S / W$ & 5 & $<30$ & 00 & $a$ & 67 & 15 & $b$ & 108 & 05 & $b$ \\
\hline
\end{tabular}

Groups of five pigs were ımmunized intramuscularly with IPPV plus different adjuvants at weeks 0 and 3 Antıbody titres were measured at week 0 3 and 6 by serum neutralızatıon Mean value, se $m$ and statıstıcal significance (S) of the results are represented Groups whıch are not statıstically different $(p>005)$ are indicated by the same letter

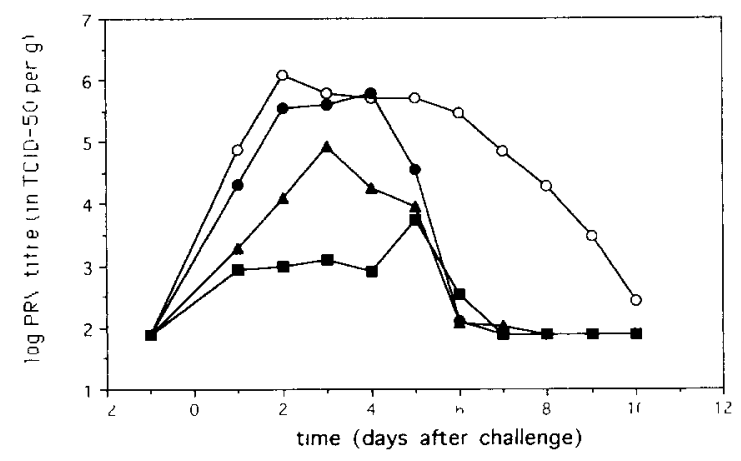

Figure 4 Virus excretion by vaccinated and non-vaccinated pigs at different tıme intervals after challenge with virulent PRV Mean titres of virus in nasal fluid of unvaccinated pigs $(O)$, anımals vaccinated twice with live PRV without adjuvant (O), live PRV $+\mathrm{O} / \mathrm{W}$ (A) or live PRV + SLP/S/W

calculated The surviving unvaccinated anımals excreted large amounts of virus during the time period from 1 to 10 days after challenge Titres higher than $10^{5}$ virus particles per gram of sample were detected over a period of 6 days (days 1-7 after challenge) and virus excretion lasted for 10 days Animals that received antigen without adjuvant also excreted high amounts of PRV during the first 5 days but no significant excretion could be observed beyond day 7 postchallenge Immunization of animals with live PRV plus adjuvant significantly reduced virus excretion Animals immunized with PRV plus $O / W$ excreted over 4 consecutive days $10^{4}-10^{5}$ TCID $_{50} \mathrm{~g}^{-1}$ while those injected with SLP/S/W excreted about $10^{4}$ TCID $_{50}$ of virus for only 1 day

Areas under the curves (AUCs) and above the background values ( $1 \mathrm{e} 10^{2}$ TCID $_{50} \mathrm{~g}^{-1}$ ) were calculated by integration and that of the group of control animals was considered to be $100 \%$ Vaccination of anımals with antigen alone reduced the AUC to $57 \%$ Vaccination with $\mathrm{O} / \mathrm{W}$ and SLP/S/W resulted in AUCs of 40 and $36 \%$, respectively

\section{Adjuvant activity of SLP/S/W and $O / W$ for the antibody response against iPPV}

Groups of pigs were immunized twice with 1 PPV plus etther SLP/S/W or $\mathrm{O} / \mathrm{W}$ as adjuvant and antibody titres were measured at different time intervals (Table 3) Before immunization, no antibodies were detected After the first injection, significant antibody titres in serum were observed and both adjuvants appeared to be equally effective Responses increased upon the second injection with vaccine and SLP/S/W evoked a significantly higher titre than $\mathrm{O} / \mathrm{W}$

\section{DISCUSSION}

In the literature, many adjuvants have been described but most data have been obtained from studies in laboratory animals Efficacy of these experimental adjuvants in target animals is often disappointing In this paper we described the adjuvant activity of a novel formulation in the target anımal species, $1 \mathrm{e}$ pigs It is the outcome of an extensive research programme on non-mineral oıl adjuvants for veterınary purposes which included the screening of a large number of different compounds and formulations in mice or guinea-pigs and subsequent testıng of promising substances in target anımal species In laboratory animals, several exper1mental adjuvants displayed distinct activity with the different types of antigens tested and only those which exhibited strong overall activity were tested in target species Among several others, an experimental formulation comprising a synthetic polysucrose derivatized with sulfate and lipid groups and incorporated into a squalane-1n-water emulsion (SLP/S/W) appeared to exert strong adjuvanticity against a protein, a hapten carrier, and two viral antigens ${ }^{10}$ Subsequent testing in pigs revealed that this $\mathrm{SLP} / \mathrm{S} / \mathrm{W}$ was significantly more effective than several other experımental formulations (data not shown) As reported here, it enhanced antibody responses against three inactivated influenza viruses, inactivated and live PRV, and against inactivated PPV Relative to negative controls which received antigen without adjuvant, ant1-influenza antibody titres were increased 315- to 478-fold Humoral responses against ${ }_{1} P R V$ and live PRV were increased 69- and 23-fold, respectively As compared with the commercially applied $\mathrm{O} / \mathrm{W}$ adjuvant, SLP/S/W was about three- to fourfold more effective in stimulating responses against the three influenza virus strains tested, live PRV and $1 P P V$, and equally effective in enhancing responses against $1 P R V$ The two constituent substances SLP and S/W also augmented responses against the viral antigens but the combination thereof demonstrated synergistic activity Similar beneficial interaction has been observed in mice and guinea-pıgs ${ }^{10}$ In principle, adjuvants are used to compensate for lack of potency of inactivated antigens as compared with their live counterparts Experiments with inactivated and live PRV revealed that immune responses against both types of antigens can be enhanced upon addition of an adjuvant The stimulatory effect of adjuvants on the immunity induced by live antigens has been reported previously ${ }^{11}$ i2 and has resulted in improved vaccines against Aujeszky disease Considerable differences were seen in levels of ant1-PRV antibody responses against either inactivated or live PRV Live PRV vaccine without adjuvant evoked antibody levels 
that were comparable with those obtained by 1 PRV plus adjuvant The possibility of increasing responses against live PRV by an adjuvant suggests that the immune system may not always react maxımally to a live virus antigen

Increased antıbody titres against live PRV upon vaccination corresponded closely to decreased titres of virus in nasal fluid at different intervals after challenge with virulent PRV A comparable, inverse relationship between humoral response and protection against virus excretion has been described by other investigators ${ }^{11,13}$ The role of circulating antibodies in protection against virus excretion can be deduced from investigation with inactivated antigen administered parenterally as this route of immunization is thought to be incapable of inducing significant levels of either cell-mediated or local immunity Intramuscular immunization of animals with purffied protein gp50 of PRV evoked neutralızing antibodies in serum and reduced virus excretion upon challenge ${ }^{13}$

Adjuvanticity of mineral oil emulsions is believed to be at least partially related to the persistence of o1l components in the host, as emulsions of oll of either vegetable or anımal origin are considerably less effective Additional active substances such as microbial glycolipids ${ }^{14}$, synthetic block polymers of polyoxyethylene and polyoxypropylene with or without microbial products $^{15}$, avridine ${ }^{16}$ or SLP, can compensate for low activity of the biodegradable oil emulsions

The SLP/S/W adjuvant formulation was developed to replace mineral onl-based adjuvants, thereby reducing toxic side-effects of vaccination Vaccines at present used in pigs often contain $25-60 \%$ mineral oil Concentrations of SLP and squalane used in the experimental vaccines are considerably lower, namely 05 and $5 \%$ respectively Furthermore, low toxicity and high biocompatibility of squalane is expected since squalane is a normal constituent of animal tissue and as such is present in low concentrations in most anımal species Next to squalene, it is the most common hydrocarbon in human sebum ${ }^{17}$ As a consequence, plain emulsions of squalane are considered to be biodegradable and to be of low or no risk to consumers of food containing residues thereof Toxicological studies on squalane affirmed relative safety ${ }^{17}$ Squalane has been used in cosmetics in high concentrations for more than 25 years and in pharmaceuticals as a carrier for lipid drugs ${ }^{17}$ The SLP used in this novel adjuvant formulation is a new chemical entity and besides immunostımulatory activity, biological effects are not known As it is built up of naturally occurring compounds, 1 e sucrose, fatty acids and sulfate, low toxicity of SLP and degradation products might be expected The sugar backbone, Ficoll-400, is a relatively inert copolymer of sucrose and epıchlorohydrin and degradation of SLP in vivo is considered to include cleavage of lipid and sulfate-ester bonds rather than breakdown of the polymer Such a degradation will yield fatty acids, sulfate and polysucrose Taking into account (1) low doses of active components, (2) biocompatıbility of squalane, (3) chemical composition and the most likely route of degradation of SLP, and (4) very low absorption rate of a polysucrose analogue with a 25 -fold lower molecular weight by the gastrointestinal tract $^{18,19}$, SLP/S/W is thought to be of low risk to the consumers of food made from anımals treated with this adjuvant
In summary, the novel SLP/S/W is an effective adjuvant for humoral responses against influenza virus strains A/Swine, MRC-11 and X-79, for inactivated and live PRV and for 1 PPV, and the two active components (1 e SLP and S/W) interact synergistically Despite lower doses of active substances and biocompatibility of the orl component, it is more effective overall than the $\mathrm{O} / \mathrm{W}$ adjuvant currently used As far as we know, this is the first tıme that a non-mineral oll adjuvant has been proven to have such a high efficacy in pigs and thus it is a potential candidate for use in porcine vaccines

\section{REFERENCES}

1 Straw, B E , Maclachlan, N J, Corbett, W T, Carter, P B and Schey, HM Comparison of tissue reactions produced by Haemophilus pleuropneumoniae vaccines made with six different adjuvants in swine Can J Comp Med 1985, 49, 149-151

2 Franchını, $A$ and Pırettı, $M V$ Indagine suı constıtuentı ıdrocarburıcı presentı in tessutı dı pollo inoculato con un vaccıno a virus spento ed emulsıonato con olı mıneralı, contro la malattıa dı Newcastle Clin Vet 1979, 102, 301-308

3 Pırettı, MV and Hubocher, G Investıgation of hydrocarbons found in the tissues of chickens injected with inoculated oll adjuvant vaccine $Z$ Lebensm Unters Forsch 1982, 175, 245-248

4 Franchını, A, Pırettı, MV, Tubertını, O, Govonı, S and Sapıgnı, R Hydrocarbons in hens injected with inactivated oil adjuvant vaccine Poultry ScI 1984, 63, 2504-2507

5 Woodhour, A F, Metzgar, D P , Stım, T B, Tytell, A A and Hilleman, $M R$ New metabolizable immunologıc adjuvant for human use । Development and anımal ımmune response Proc Soc Exp Bıol Med 1964, 116, 516-523

6 Fukumı, $\mathrm{H}$ Effectiveness and untoward reactions of oll adjuvant influenza vaccines in Symposia Series in Immunobiological Standardization 6 international Symposium on Adjuvants of Immunity (Eds Regamey, R H, Hennessen, W, Ikıc, D and Ungar, J) Krager, Basel, 1967, pp 237-240

7 Hilleman, M R The clınical application of adjuvant-65 Ann Allergy 1972, 30, 152-158

8 Reynolds, J A, Harrıngton, D G, Crabbs, CL, Peters, C J and Dı Luzıo, NR Adjuvant activity of a novel metabolizable lıpıd emulsıon with inactivated viral vaccines Infect Immun 1980, 28, 937-943

9 Stone, HD and Xie, Z Effıcacy of experımental Newcastle disease water-In-oll emulsions vaccines formulated from squalane and squalene Avian Dis 1990, 34, 979-983

10 Hilgers, L A Th, Platenburg, P L I, Luitjens, A, Groenveld, B Dazelle, $T$, Ferrari-Laloux, $M$ and Weststrate, $M W$ A novel non-mıneral oıl based adjuvant I Efficacy of a synthetıc sulfolıpopolysaccharıde in a squalane-ın-water emulsion in laboratory anımals Vaccıne 1994, 12, 653-660

11 Vannier, P, Hutet, E, Bourguell, E and Carıolet, R Level of virulent virus excreted by infected pigs previously vaccinated with different glycoprotein deleted Aujeszky's disease vaccines Vet Microbiol 1991, 29, 213-223

12 Duphar BV, European Patent EP 0129 923, 1988

13 Mukamoto, M, Watanabe, I, Kobayashı, Y, Icatlo, F C, Ishı, H and Kodama, $Y$ Immunogenıcity in Aujeszky's disease virus structural glycoprotein gVI (gp50) in swine Vet Microbiol 1991, 29, 109-121

14 Allison, A C and Byars, NE An adjuvant formulation that selectively elicits the formation of antibodies of protective isotypes and cell-mediated immunity $J$ Immunol Methods 1986, 95, 157-168

15 Ribı, E Structure-function relationship of bacterial adjuvants In Advances in Carriers and Adjuvants for Veterinary Bıologics (Eds Nervig, $R M$ M , Gough, P M , Kaeberle, $M L$ and Whetstone, $C A$ ) lowa State University Press, Ames, IA, pp 35-50

16 Woodard, LF and Jasman, RL Stable oll-in-water emulsıons preparation and use as vaccıne vehıcles for lıpophilıc adjuvants Vaccine 1985, 3, 137-144

17 Bush, $J$ Final report on safety assessment of squalane and squalene $J \mathrm{Am}$ Coll Toxicol 1982, 1, 37-56

18 Öman, $H$, Hendriksson, $K$, Blomqvist, $L$ and Johansson, $G$ Intestınal permeability to Ficoll in patients with rheumatoid arthritis XVII ILAR Congress of Rheumatology, Rio de Janeıro, Brazıl, 1989 p 299

19 Park, P-O, Frodın, L, Haglund, U, Tutveson, G and Öman, H Rapıd evaluation of graft integrity after small bowel transplantation Eur J Surg 1991, 157, 669-673 